\title{
Peranan Penyuluh Swadaya dalam Mendukung Intensifikasi Kakao di Kabupaten Sigi Provinsi Sulawesi Tengah
}

\section{The Role of self-Support Extension Agents in Supporting Intensification Cocoa in Sigi District Central Sulawesi}

\author{
Riana $^{1}$, Ninuk Purnaningsih ${ }^{2}$, Arif Satria ${ }^{2}$ \\ ${ }^{1}$ Program Studi ilmu Penyuluhan Pembangunan, Sekolah Pascasarjana Institut Pertanian Bogor, Bogor \\ ${ }^{2}$ Departemen Sains Komunikasi dan Pengembangan Masyarakat, \\ Fakultas Ekologi manusia, Institut Pertanian Bogor, Bogor
}

\begin{abstract}
Self-support extension agents is the main actors who are successful in their business and other community members with his own conscience willing and able to become a counselor. The role of self support extension agents is needed to support the role of civil servants as an alternative that is deemed in accordance with UUNo. 16 2006th. But there are still many people, including the main actors themselves who do not know the important role of the non-extension. The purpose of this study is to analyze the role of self-support extension agents in supporting intensification extension cocoa viewed from the aspect of agribusiness. This research is descriptive quantitative survey method with descriptive analysis approach and quantitative paradigm. Research carried out in the Sigi district of Central Sulawesi, which became one of the central largest cocoa producing. The sample in this study is a cocoa farmer extension built by self-help by using the method of proportional cluster random sampling as 96 people. Overall results of farmers' perceptions of the role of self-support extension agents was that extension workers has been instrumentalin supporting themselves-intensification cocoa butonly dominant in farming sector. This happened because the they just get extension related to the cultivation. Whereas if the extension self-given knowledge relating to the harvest and postharvest and marketing, the role will become more important as supported also by extension the role of self-support extension agents in motivating and help the farmers in the problem solving.
\end{abstract}

Keywords: role, self-support extension agents, cocoa, farmer's perception

\begin{abstract}
Abstrak
Penyuluh swadaya adalah pelaku utama yang berhasil dalam usahanya dan warga masyarakat lainnya yang dengan kesadarannya sendiri mau dan mampu menjadi penyuluh. Peranan penyuluh swadaya saat ini sangat dibutuhkan untuk mendukung peranan penyuluh PNS sebagai alternatif yang dipandang sesuai dengan UU RI Nomor 16 Tahun 2006. Masih banyak orang termasuk pelaku utama sendiri yang belum mengetahui peranan penting dari penyuluh swadaya tersebut. Tujuan penelitian ini adalah menganalisis peranan penyuluh swadaya dalam mendukung intensifikasi kakao dilihat dari aspek agribisnis. Penelitian ini merupakan penelitian deskriptif kuantitatif menggunakan metode survei dengan pendekatan analisis deskriptif dan paradigma kuantitatif. Penelitian dilakukan di Kabupaten Sigi Provinsi Sulawesi tengah yang menjadi salah satu sentral penghasil kakao terbesar. Sampel dalam penelitian ini adalah petani kakao yang dibina oleh penyuluh swadaya dengan menggunakan metode cluster proporsional random sampling sebanyak 96 orang. Hasil dari persepsi petani terhadap peranan penyuluh swadaya secara keseluruhan, penyuluh swadaya telah berperan dalam mendukung intensifikasi kakao akan tetapi hanya dominan pada sektor budidaya. Hal ini terjadi karena penyuluh swadaya lebih banyak mendapatkan penyuluhan yang berhubungan dengan budidaya saja. Jika penyuluh swadaya mendapatkan pengetahuan yanglain tentang panen dan pascapanen serta pemasaran maka peranannya menjadi lebih baik. Didukungpula oleh peranan penyuluh swadaya dalam memberikan motivasi dan membantu petani dalam menyelesaikan masalahnya.
\end{abstract}

Kata Kunci: peranan, penyuluh swadaya, kakao, persepsi petani

\section{Pendahuluan}

Pemerintah Indonesia melalui kementerian pertanian telah mencanangkan program satu penyuluh satu desa, namun jumlah penyuluh belum mencukupi kebutuhan yang seharusnya yaitu 72.143 penyuluh dan baru terpenuhi sekitar 85\% (Departemen Pertanian,
2013). Menurut UU Nomor 16 tahun 2006 tenaga penyuluh terdiri dari penyuluh PNS, penyuluh swasta dan/atau penyuluh swadaya. Penyuluh pertanian, penyuluh perikanan, atau penyuluh kehutanan, baik penyuluh PNS, swasta, maupun swadaya yang selanjutnya disebut penyuluh. Jumlah penyuluh swadaya di Indonesia saat ini berjumlah 13.169 penyuluh

\footnotetext{
${ }^{1}$ Korespondensi penulis

E-mail: rianadahlan@gmail.com
} 
sedangkan penyuluh PNS berjumlah 27.476 penyuluh. Keberadaan penyuluh swadaya sebagai alternatif pemenuhan kebutuhan penyuluh belum mencukupi untuk mengatasi kekurangan tersebut.

Penyuluh swadaya memiliki peranan penting termasuk juga di Kabupaten Sigi yang merupakan kabupaten baru dengan jumlah penduduk mencapai 219.005 jiwa yang tersebar di 15 kecamatan. Perkebunan merupakan salah satu sektor pertanian yang menjadi andalan Kabupaten Sigi. Pada tahun 2011 produksi kakao Kabupaten Sigi sebanyak 18.386,50 ton dengan luas area 27.555,10 ha kabupaten Sigi termasuk penghasil kakao terbesar di Sulawesi Tengah (Badan Pusat Statistik Provinsi Sulawesi Tengah, 2013). Kabupaten Sigi merupakan sasaran utama dari Gerakan Peningkatan Produksi dan Mutu Kakao Nasional melalui program rehabilitasi, peremajaan dan intensifikasi perkebunan yang dilaksanakan oleh Departemen Pertanian pada tahun 2009 sampai tahun 2013.

Penyuluh swadaya sebagai pelaku utama yang telah berhasil dalam usaha taninya seharusnya mampu memainkan perannya untuk membantu pemerintah sehingga petani lain memiliki motivasi yang tinggi untuk berhasil dalam usaha taninya dan lebih mandiri, memiliki daya saing dan peningkatan kesejahteraan. Sejalan dengan hasil penemuan studi yang dilakukan oleh Kurnia Suci Indraningsih (2010) menunjukkan bahwa penyuluh swadaya merupakan pelaku utama yang memiliki status sosial yang tinggi. Hal ini mengindikasikan kebutuhan penyuluh swadaya akan peranannya. Berbagai peranan tersebut diterapkan oleh penyuluh dengan kadar yang berbeda.

Berdasarkan uraian di atas, maka tujuan dalam penelitian ini adalah menganalisis peranan penyuluh swadaya dalam mendukung intensifikasi kakao di Kabupaten Sigi Provinsi Sulawesi Tengah.

\section{Metode Penelitian}

Berdasarkan tujuan penelitian, jenis penelitian yang digunakan adalah penelitian deskriptif kuantitatif (Singarimbun dan Effendi, 1989), menggunakan metode survei dengan pendekatan analisis deskriptif dan paradigma kuantitatif sesuai pendapat Miller, Black dan Champion (Sumardjo, 1999) sebagai tumpuan analisis, dilengkapi dengan informasi berdasarkan data kualitatif sesuai pendapat Dey dan Moleong (Sumardjo, 1999) untuk mendukung dan mempertajam analisis kuantitatif. Jenis data yang dikumpulkan terdiri dari data primer dan data sekunder. Data primer diperoleh melalui wawancara, pengisian kuesioner maupun FGD dengan teknik "search conference" baik kepada responden maupun informan, sedangkan data sekunder diperoleh dari hasil penelitian terdahulu dan kajian pustaka yang relevan serta data yang telah dikumpulkan pihak lain seperti Badan Penyuluhan, serta instansi pemerintah lainnya.

Penelitian dilakukan di Kabupaten Sigi Biromaru Provinsi Sulawesi Tengah. Pemilihan lokasi dilakukan secara purposive dengan pertimbangan bahwa Kabupaten Sigi merupakan Kabupaten baru yang menjadikan perkebunan menjadi salah satu sektor yang mendukung perekonomian daerah. Populasi dalam Penelitian ini adalah petani kakao yang dibina oleh penyuluh swadaya berjumlah 2.150 orang. Teknik Pengambilan sampel dilakukan dengan menggunakan metode cluster proporsional random sampling sebanyak 96 orang. Dengan menggunakan rumus sebagai berikut :

$$
\mathrm{n}=\mathrm{N} /\left(\mathrm{Nd}^{2}+1\right)
$$

Keterangan :

n : Jumlah Sampel

$\mathrm{N} \quad$ : Jumlah Populasi

d2 : Presisi (ditetapkan 10\% dengan tingkat kepercayaan 90\%)

Data yang diperoleh dianalisis dengan metode skoring. Seluruh kriteria ditentukan nilainya berdasarkan Skala Likert. Skor responden dijumlahkan, kemudian dihitung rata-ratanya. Dari hasil rata-rata yang diperoleh, kemudian ditentukanlah masuk ke golongan apa posisi penilaian responden. Hasil perhitungan tersebut kemudian dipergunakan untuk membuat klasifikasi tingkat peranan penyuluh swadaya.

\section{Hasil dan Pembahasan}

\section{Gambaran Umum Kabupaten Sigi}

Luas wilayah Kabupaten Sigi secara keseluruhan adalah 5.196,02 $\mathrm{km}^{2}$ atau sekitar 7,64\% dari total luas wilayah Sulawesi Tengah lebih kecil jika dibandingkan dengan Kabupaten Parigi Moutong yang sama-sama penghasil kakao dengan luas sekitar 9,16\%. Secara 
Tabel 1 Jumlah sebaran responden di Kabupaten Sigi

\begin{tabular}{clcc}
\hline No. & \multicolumn{1}{c}{ BP3K } & $\begin{array}{c}\text { Jumlah } \\
\text { Populasi }\end{array}$ & $\begin{array}{c}\text { Jumlah } \\
\text { Sampel }\end{array}$ \\
\hline 1. & Baluase & 50 & 2 \\
2. & Dolo & 50 & 2 \\
3. & Kulawi & 725 & 33 \\
4. & Palolo \& Nokilalaki & 825 & 37 \\
& (Bahagia) & & 22 \\
5. & Kulawi Selatan (Lawua) & 500 & 96 \\
\hline Jumlah & 2.150 & \\
\hline
\end{tabular}

administratif, Kabupaten Sigi terbagi menjadi 15 kecamatan,masing-masing kecamatan tersebut terbagi menjadi beberapa wilayah administrasi di bawahnya yaitu desa/UPT. Hingga tahun 2012, terdapat 156 desa dan 1 UPT di wilayah Kabupaten Sigi, sedangkan wilayah administrasi setingkat kelurahan masih belum terbentuk. Kabupaten Sigi beribukota di Bora, sekitar 16 km dari Kota Palu. Secara umum, wilayah Kabupaten Sigi dapat ditempuh melalui jalur darat dengan jarak antar ibukota kecamatan dengan ibukota kabupaten yang beragam.

Berdasarkan ketinggian ibukota kecamatan yang diukur menggunakan GPS di titik-titik kantor camat, ketinggian wilayah Kabupaten Sigi berkisar $32 \mathrm{~m}$ sampai $1.350 \mathrm{~m}$ diatas permukaan laut, dimana titik terendah berada di Kantor Camat Dolo (Kota Pulu) dengan komoditasnya kelapa dan kakao dan titik tertinggi di Kantor Camat Marawola Barat (Dombu) dengan komoditas kopi, kemiri, vanili, kakao dan cengkeh (BPS Provinsi Sulawesi Tengah, 2013)

Komposisi penduduk Kabupaten Sigi menurut struktur umur adalah sekitar 33\% penduduk masih berusia di bawah 15 tahun. Sementara itu, sekitar 63\% penduduk Kabupaten Sigi berada diusia produktif (15-64 tahun) dan 4\% diusia 65 tahun ke atas. Hal ini menunjukkan bahwa penduduk Kabupaten Sigi masih tergolong penduduk muda. Sebagian besar penduduknya bekerja di sektor Pertanian dan yang menjadi salah satu andalannya adalah sub sektor Pertanian tanaman pangan khususnya padi sawah dan sub sektor perkebunan khususnya kakao. Produksi tanaman kakao di Kabupaten Sigi pada tahun 2013 sebanyak $18.386,50$ ton dan daerah penghasil kakao terbesar adalah kecamatan palolo dengan luas tanam $10.752,80$ ha dengan jumlah produksi sebesar 9.484,70 ton pertahun (BPS Provinsi Sulawesi
Tengah, 2013).

\section{Karakteristik Responden}

Karakteristik responden merupakan penciri dari masing-masing responden yang meliputi umur, pendidikan formal, pengalaman berusahatani dan pengetahuan petani terhadap peranan penyuluh swadaya (Tabel 1).

\section{Umur Responden}

Berdasarkan data yang diperoleh, diketahui sebagian besar responden berada di usia produktif di antara 15-64 tahun (BKKBN, 2013). Rentang usia terbanyak adalah 26-40, usia yang produktif ini memungkinkan responden untuk aktif dalam memberikan persepsi mereka terhadap peranan penyuluh swadaya. Umur akan mempengaruhi seseorang dalam merespon sesuatu yang baru walaupun belum banyak mempunyai pengalaman dan akan lebih mudah serta cepat dalam menerima inovasi. Hal tersebut sejalan dengan pernyataan Lionberger (1960) dalam Mardikanto (2007) yang menyatakan semakin tua (di atas 50 tahun) biasanya semakin lamban mengadopsi inovasi dan cenderung banyak melaksanakan kegiatankegiatan yang sudah biasa diterapkan oleh warga masyarakat setempat.

\section{Pendidikan Formal}

Pendidikan formal responden pada penelitian ini lebih banyak adalah tamatan SD yang dihitung berdasarkan tahun pendidikan yaitu $47 \%$ yang berarti berada pada kategori rendah. Pendidikan formal merupakan lama pendidikan yang ditempuh responden pada bangku sekolah. Mengacu pada pendapat 
Tabel 2 Karakteristik responden di Kabupaten Sigi tahun 2015

\begin{tabular}{cllc}
\hline No & \multicolumn{1}{c}{ Variabel } & \multicolumn{1}{c}{ Kriteria } & Persentase (\%) \\
\hline 1. & Umur Responden & Tua $(>55)$ & 11,45 \\
& & Dewasa $(41-55)$ & 37,50 \\
& & Muda $(26-40)$ & 51,05 \\
& Rataan : 42 & Tinggi $(>11$ tahun) & \\
2. & Pendidikan Formal & Sedang $(9-11$ tahun) & 29,20 \\
& & Rendah (6 - 8 tahun) & 24,96 \\
& & & 47,00 \\
& Rataan : 9 & Tinggi ( $>30$ tahun) & \\
3. Pengalaman berusahatani & Sedang (18 - 30 tahun) & 2,08 \\
& & Rendah (5 - 17 tahun) & 46,87 \\
& & & 51,05 \\
& Rataan : 17 & Tinggi (Tepat) & 3,12 \\
4. Pengetahuan Petani & Sedang (Kurang Tepat) & 39,58 \\
& & Rendah (Tidak Tepat) & 57,30 \\
& & & 100,00 \\
\hline
\end{tabular}

Soekartawi (1988) dan Roger dan Shoemaker (1971) suatu tantangan bagi penyuluhan pertanian dalam mengembangkan pembelajaran yang menarik bagi petani dengan tingkat pendidikan yang relatif masih rendah sehingga dapat menerapkan adopsi dengan lebih cepat.

Jarak tempuh yang cukup jauh dan infrastruktur yang kurang memadai di desa tempat petani tinggal dengan fasilitas pendidikan tidak mendukung untuk mereka menempuh pendidikan yang lebih tinggi. Hal tersebut yang akhirnya membuat petani puas dengan pendidikan mereka yang hanya bisa diraih hingga 6-9 tahun masa pendidikan. Keinginan yang lemah dan biaya pendidikan juga menjadi faktor lain sehingga mereka tidak mengencam pendidikan hingga perguruan tinggi.

\section{Pengalaman Berusahatani}

Pengalaman berusahatani responden binaan penyuluh swadaya pada penelitian ini adalah 5-17 tahun dengan presentase sebesar $51,05 \%$ yang dikategorikan rendah. Pengalaman berusahatani dalam penelitian ini merupakan tahun lamanya responden bekerja sebagai petani dibidang perkebunan kakao sampai saat penelitian ini dilakukan. Pengalaman berusahatani cenderung mempengaruhi keputusan yang akan diambil petani pada kegiatan usahatani berikutnya. Sebelum bertani kakao, petani merupakan penanam vanili. perubahan jenis tanaman dari vanili ke kakao dikarenakan adanya program dari pemerintah dengan bantuan penyuluh swadaya yang mulai mengalihfungsikan lahan mereka.

Ada beberapa dari responden penelitian ini memiliki pengalaman berusahatani kakao lebih lama dibanding penyuluh swadaya itu sendiri, hal ini dikarenakan banyak dari petani kakao yang bertani karena keturunan atau secara turun temurun. Sebagian responden penelitian ini memiliki pengalaman lain selain bertani kakao yakni sebagai petani jagung maupun padi. sedangkan untuk petani kakao yang sudah memiliki pengalaman dalam kategori sedang dan tinggi mereka masih menerima informasi dari penyuluh swadaya untuk pengembangan usahatani kakao mereka dan penyuluh swadaya juga menjadikan mereka sebagai partner dalam berbagi pengalaman.

\section{Pengetahuan Petani terhadap Peranan Penyuluh swadaya}

Pengetahuan yang dimaksud dalam penelitian ini adalah informasi yang diterima oleh petani tentang peranan penyuluh swadaya. Berdasarkan hasil lapang bahwa jawaban dari point-point yang ditanyakan kepada responden tentang pengetahuan 
Tabel 3 Persepsi petani terhadap peranan yang dilakukan oleh penyuluh swadaya dalam proses budidaya kakao

\begin{tabular}{llccl}
\hline No & \multicolumn{1}{c}{$\begin{array}{c}\text { Peranan yang dilakukan } \\
\text { penyuluh swadaya }\end{array}$} & $\begin{array}{c}\text { Persentase } \\
\text { (jawaban } \\
\text { “ya") }\end{array}$ & $\begin{array}{c}\text { Rata-rata untuk } \\
\text { seluruh jawaban } \\
\text { responden }\end{array}$ & Kategori \\
\hline 1. & Perencanaan & 0,00 & 1,45 & Tidak berperan \\
2. & Pengolahan tanah & 2,08 & 1,06 & Tidak berperan \\
3. & Penanaman tanaman pelindung & 15,62 & 1,51 & Tidak berperan \\
4. & Pembenihan & 30,20 & 2,03 & Cukup berperan \\
5. & Pemangkasan & 42,70 & 2,40 & Berperan \\
6. & Pemupukan & 79,17 & 2,80 & Berperan \\
7. & Pengendalian hama & 60,42 & 2,55 & Berperan \\
8. & Pengendalian penyakit & 57,30 & 2,55 & Berperan \\
9. & Pengendalian gulma & 8,33 & 1,89 & Tidak berperan \\
10. & Evaluasi & 0,00 & 1,06 & Tidak berperan \\
\hline
\end{tabular}

petani terhadap peranan penyuluh swadaya yang sesuai dengan juklak pemberdayaan dan pembinaan penyuluh swadaya dikategorikan kurang tepat dengan presentase $87,50 \%$. Hal ini terjadi karena rata-rata petani yang dibina oleh penyuluh swadaya tidak mengetahui tugas dan fungsi sebenarnya dari penyuluh swadaya, sebagian responden menganggap penyuluh swadaya hanya sebagai ketua kelompok yang membantu mereka ketika mempunyai masalah dan mencarikan solusinya dan orang yang bisa langsung berkomunikasi dengan pihak pemerintah dalam hal ini Badan Pelaksana Penyuluhan Pertanian, Perikanan dan kehutanan Kecamatan (BP3K) ketika ada masalah yang tidak dapat diselesaikan oleh petani maupun penyuluh swadaya. Maka perlu adanya sosialiasasi kepada petani bahwa selain penyuluh pertanian PNS adapula penyuluh swadaya yang berasal dari kalangan petani. Hal ini perlu dilakukan demi kebaikan kedepannya agar petani mengetahui benar peranan penyuluh swadaya sehingga nantinya mereka lebih terbuka ketika ada masalah usahatani kakao yang mereka hadapi dan hal-hal lain yang berhubungan dengan tugas dan fungsi penyuluh swadaya.

Pengetahuan merupakan hal yang penting bagi seseorang begitu pula bagi petani sebagai acuan mereka untuk dapat mengungkapkan pendapat mereka, semakin baik pengetahuan petani tentang peranan penyuluh swadaya dan semakin banyak informasi yang mereka dapatkan maka semakin berpengaruh terhadap persepsi petani baik itu persepsi positif atau negatif, seperti halnya yang diungkapkan oleh Sugihartono et al., (2007) bahwa persepsi seseorang memiliki sudut pandang yang berbeda dalam penginderaan baik itu persepsi negatif maupun positif. Tergantung kecenderungan seseorang dalam melihat benda yang sama dengan cara yang berbedabeda. Perbedaan tersebut bisa dipengaruhi oleh banyak faktor di antaranya adalah pengetahuan dan sudut pandang.

\section{Peranan Penyuluh Swadaya}

Peranan merupakan perangkat tingkah laku yang diharapkan dimiliki oleh seseorang yang berkedudukan di masyarakat. Peranan menurut Grass, Mason dan MC Eachern yang dikutip dalam buku pokok-pokok pikiran dalam sosiologi karangan David Berry (1995) mendefinisikan peranan sebagai perangkat harapanharapan yang dikenakan pada individu atau kelompok yang menempati kedudukan sosial tertentu. Selanjutnya dikemukakan oleh Soekanto (2002), bahwa peranan (role) merupakan aspek dinamis kedudukan (status). Apabila seseorang melaksanakan hak dan kewajibannya sesuai kedudukannya, maka ia menjalankan suatu peranan. Berdasarkan dua pengertian di atas, peranan adalah perangkat harapan-harapan yang dikenakan pada individu atau kelompok untuk melaksanakan hak dan kewajiban yang harus dilaksanakan oleh pemegang peran sesuai dengan yang diharapkan masyarakat.

Peran penyuluh menurut Undang-undang nomor 16 tahun 2006, adalah memberdayakan pelaku utama dan 
Tabel 4 Persepsi petani terhadap peranan yang dilakukan oleh penyuluh swadaya dalam proses panen dan pascapanen

\begin{tabular}{llccl}
\hline No & $\begin{array}{c}\text { Peranan yang dilakukan } \\
\text { penyuluh swadaya }\end{array}$ & $\begin{array}{c}\text { Persentase } \\
\text { (jawaban "ya") }\end{array}$ & $\begin{array}{c}\text { Rata-rata } \\
\text { untuk seluruh } \\
\text { jawaban } \\
\text { responden }\end{array}$ & Kategori \\
\hline 1. & Pemetikan & 10,42 & 1,81 & Tidak berperan \\
2. & Penyortiran & 1,05 & 1,38 & Tidak berperan \\
3. & Pembelahan Buah & 0,00 & 1,33 & Tidak berperan \\
4. & Fermentasi & 0,00 & 1,27 & Tidak berperan \\
5. & Pengolahan & 0,00 & 1,26 & Tidak berperan \\
\hline
\end{tabular}

pelaku usaha dalam peningkatan kemampuan melalui penciptaan iklim usaha yang kondusif, penumbuhan motivasi, pengembangan potensi, pemberian peluang, peningkatan kesadaran, dan pendampingan serta fasilitasi. Adapun kedudukan Penyuluh pertanian swadaya dalam Peraturan Menteri Pertanian nomor 61 tahun 2008 adalah sebagai mitra penyuluh pertanian PNS dalam melakukan kegiatan penyuluhan pertanian, baik sendiri-sendiri maupun kerjasama yang terintegrasi dalam programa penyuluhan pertanian sesuai dengan tingkat administrasi pemerintahan dimana kegiatan penyuluhan diselenggarakan. Keberadaan penyuluh pertanian swadaya bersifat mandiri dan independen untuk memenuhi kebutuhan pelaku utama dan pelaku usaha pertanian. Sedangkan tugas pokok penyuluh pertanian swadaya adalah melakukan kegiatan penyuluhan pertanian kepada pelaku utama dan pelaku usaha sesuai dengan rencana kerja penyuluhan pertanian yang disusun berdasarkan programa penyuluhan pertanian di wilayah kerjanya.

Berikut ini adalah persepsi petani terhadap peranan penyuluh swadaya yang dilihat berdasarkan aspek agribisnis yakni budi daya, panen dan pascapanen serta pemasaran dan didukung dengan persepsi petani terhadap peranan penyuluh swadaya berdasarkan pada Standar Kompetensi Kerja Nasional Indonesia (SKKNI) yang berlaku bagi penyuluh pertanian PNS, swasta maupun swadaya.

\section{Peranan Penyuluh Swadaya dalam Proses Budidaya Kakao}

Budidaya tanaman bertujuan untukmeningkatkan dan memperluas penganekaragaman hasil tanaman, guna memenuhi kebutuhan, meningkatkan pendapatan dan taraf hidup petani serta mendorong perluasan dan pemerataan kesempatan berusaha dan kesempatan kerja (UU nomor 12 tahun 1992 Tentang Sistem Budi daya Tanaman).

Adapun peranan penyuluh swadaya dalam setiap tahapan budi daya tanaman kakao pada penelitian ini diantaranya adalah (1) Perencanaan budi daya tanaman kakao, (2) pengolahan tanah, (3) menanam tanaman pelindung sebelum tanam kakao, (4) pembenihan, (5) pemangkasan, (6) pemupukan, (7) pengendalian hama, (8) pengendalian penyakit, (9) pengendalian gulma, dan (10) evaluasi.

Persepsi petani terhadap peranan penyuluh swadaya dalam proses budidaya kakao lebih didominasi oleh peranan penyuluh swadaya dalam memberikan informasi tentang pemangkasan, pemupukan yang tepat dan juga pengendalian hama serta pengendalian penyakit. Hal ini disebabkan karena kebutuhan akan perawatan terhadap tanaman kakao itu sendiri. Sedangkan perencanaan tidak begitu dilakukan oleh penyuluh swadaya, berdasarkan hasil wawancara mendalam didapatkan informasi bahwa perencanaan yang dilakukan oleh penyuluh swadaya lebih bersifat non formal atau tidak langsung sesuai kondisi dari petani itu sendiri. Kebanyakan dari petani yang dibina oleh penyuluh swadaya adalah petani yang sudah memulai tanamannya sehingga penyuluh swadaya lebih berperan terhadap perawatan perkembangan dari tanaman kakao tersebut.

Begitu pula dengan proses evaluasi, sebagian besar dari penyuluh swadaya tidak melakukan evaluasi secara tertulis terhadap apa yang disampaikannya, evaluasi yang dilakukan hanya bersifat tidak langsung. Pada saat menyelesaikan masalah tentang hama atau penyakit, maka penyuluh swadaya akan bertanya tentang hasil dari solusi yang dilakukan dalam mengendalikan hama atau penyakit pada tanaman 
Tabel 5 Persepsi petani terhadap peranan yang dilakukan oleh penyuluh swadaya dalam proses pemasaran

\begin{tabular}{llccl}
\hline No & $\begin{array}{c}\text { Peranan yang dilakukan } \\
\text { penyuluh swadaya }\end{array}$ & $\begin{array}{c}\text { Rata-rata } \\
\text { Persentase } \\
\text { (jawaban “ya") }\end{array}$ & $\begin{array}{c}\text { untuk seluruh } \\
\text { jawaban } \\
\text { responden) }\end{array}$ & Kategori \\
\hline 1. & Informasi harga kakao & 5,21 & 1,77 & Tidak berperan \\
2. & Penjualan & 0,00 & 1,47 & Tidak berperan \\
3. & Kemitraan & 0,00 & 1,27 & Tidak berperan \\
\hline
\end{tabular}

kakao mereka, apakah solusi tersebut telah berhasil dilakukan ataukah ada kendala lain. Ketika petani mengalami masalah penyuluh swadaya selalu siap membantu baik itu perawatan tanaman kakao maupun mengembangkan usahatani kakaonya. Jika penyuluh swadaya tidak memiliki pengetahuan tentang apa yang menjadi masalah dari petani maka penyuluh swadaya akan bertanya kepada penyuluh PNS atau THL. Hal ini sangat perlu terus dilakukan untuk menghasilkan keharmonisasian dalam bekerjasama antar penyuluh, baik penyuluh PNS, THL maupun swadaya sehingga pemberdayaan terhadap petani dapat berhasil baik dan tercapainya tujuan dari penyuluhan dan perlu dilakukannya penyuluhan yang bersifat bottom up untuk mengetahui kebutuhan petani.

\section{Peranan Penyuluh Swadaya dalam Proses Panen dan Pascapanen}

Menurut UU No 12 tahun 1992 panen merupakan kegiatan pemungutan hasil budi daya tanaman yang ditujukan untuk memperoleh hasil yang optimal dengan menekan kehilangan dan kerusakan hasil serta menjamin terpenuhinya standar mutu. Untuk mencapai tujuan tersebut maka panen harus dilakukan dengan tepat waktu, tepat keadaan, tepat cara, dan tepat sarana. Dalam pelaksanaan panen harus dicegah timbulnya kerugian bagi masyarakat dan/atau kerusakan sumber daya alam dan/atau lingkungan hidup.

Pascapanen meliputi kegiatan pembersihan, pengupasan kakao, sortasi, pengawetan, pengemasan, penyimpanan, standardisasi mutu, dan transportasi hasil produksi budi daya tanaman. Kegiatan pascapanen ditujukan untuk meningkatkan mutu, menekan tingkat kehilangan dan/atau kerusakan, memperpanjang daya simpan, dan meningkatkan daya guna serta nilai tambah hasil budi daya tanaman. Panen dan pascapanen yang dimaksud dalam penelitian ini adalah pemetikan, penyortiran, pembelahan buah, fermentasi, pengeringan, pengolahan, mutu dan evaluasi.

Peranan penyuluh swadaya pada aspek agribisnis dalam proses panen dan pascapanen kakao adalah tidak berperan, hal ini disebabkan karena kebanyakan dari penyuluh swadaya tidak dapat berbuat apa-apa untuk membantu petani dalam proses panen dan pascapanen dikarenakan proses ini sudah dilakukan sejak petani kecil karena keseluruhan responden adalah keluarga petani dan memiliki tetangga yang juga seorang petani sehingga setiap harinya mereka melihat orang-orang disekitar mereka melakukan proses panen dan pascapanen tersebut yang kemudian mereka ikuti.

Proses fermentasi pernah dilakukan di Kecamatan Palolo, namun fermentasi tersebut dilakukan atas permintaan perusahaan. Kini perusahaan tidak lagi berada diwilayah tersebut sehingga petani tidak lagi melakukan fermentasi. Sebanyak 98\% responden menyatakan bahwa dengan melakukan fermentasi ataupun tidak, sama sekali tidak berpengaruh terhadap harga jual. proses fermentasi membutuhkan waktu lima hari dan yang tidak difermentasi hanya membutuhkan waktu dua hari pengeringan. Petani berpendapat hanya akan mengalami kerugian waktu sedangkan harga jual hanya berbeda seribu rupiah, sehingga mereka berhenti melakukan fermentasi, sedangkan untuk proses pengolahan, banyak petani yang tidak mendapatkan informasi tentang pengolahan kakao menjadi bahan jadi ataupun tidak adanya informasi teknologi yang dapat mereka lakukan untuk mengolah coklat tersebut. Pemerintah pernah melakukan penyuluhan tentang pengunaan teknologi pengolahan coklat dan bahkan telah ada alat yang diberikan oleh pemerintah, namun masih banyak petani yang belum mengetahui cara penggunaannya sehingga alat tersebut tidak pernah lagi digunakan. Adapun yang telah mengolahnya sendiri tetapi 
tidak ada pasar untuk menjual hasil olahan mereka. Penyuluh swadaya tidak mengetahui tentang teknologi tersebut. Hal ini perlu menjadi perhatian bagi pemerintah untuk benar-benar melakukan proses penyuluhan sehingga petani bukan hanya sekedar tahu namun juga dapat mempraktikkannya dan menyiapkan pasar sebagai salah satu syarat mutlak dari pembangunan pertanian (Mosher, 1991).

Penyuluh swadaya adalah pelaku utama yang berhasil dalam usahataninya dan memiliki kemauan untuk menjadi penyuluh dan tentunya hal yang paling penting dari seorang yang memiliki pengalaman adalah selalu berbagi pengalaman mereka agar menjadi pengetahuan bagi petani lain, namun demikian masih banyak penyuluh swadaya yang belum mengenal teknologi kakao termasuk juga teknologi pengolahannya. Hal ini terjadi karena belum adanya dukungan yang kontinyu terhadap peranan penyuluh swadaya. Kelembagaan yang ada didesa masih perlu penguatan sebagai upaya dalam melakukan pemberdayaan bagi penyuluh swadaya sebagaimana yang terdapat dalam Juklak Pemberdayaan Penyuluh Pertanian Swadaya Kementerian Pertanian, dengan demikian penyuluh swadaya juga mampu untuk memberdayakan petani lainnya.

\section{Peranan Penyuluh Swadaya dalam Proses Pemasaran Kakao}

Menurut American Marketing Association yang dikutip oleh Philip Kotler dan Kevin Lene Keller (2009), menyatakan bahwa:

\section{"Pemasaran adalah suatu fungsi organisasi dan serangkaian proses untuk menciptakan, mengkomunikasikan, dan memberikan nilai kepada pelanggan dan untuk mengelola hubungan pelanggan dengan cara yang menguntungkan organisasi dan pemangku kepentingan'}

Menurut pendapat W.J. Stanton (1993) pemasaran meliputi keseluruhan sistem yang berhubungan dengan kegiatan-kegiatan usaha, yang bertujuan merencanakan, menentukan harga hingga mempromosikan, dan mendistribusikan barangbarang atau jasa yang akan memuaskan kebutuhan pembeli, baik yang aktual maupun yang potensial.
Berdasarkan beberapa pendapat diatas dapat diketahui bahwa pemasaran merupakan suatu sistem manajerial untuk memenuhi kebutuhan dan keinginan seseorang maupun kelompok dengan menggunakan strategi yang bertujuan merencanakan, menentukan harga, mempromosikan dan mendistribusikan barang atau jasa yang akan memberikan kepuasan kepada pembeli. Pemasaran yang dimaksud dalam penelitian ini adalah harga, tempat penjualan dan kemitraan.

Persepsi petani terhadap peranan penyuluh swadaya dalam proses pemasaran. Pada proses ini penyuluh swadaya tidak berperan secara signifikan, namun pada waktu-waktu tertentu menurut hasil lapangan bahwa terkadang penyuluh swadaya memberikan informasi tentang harga kakao dipasaran hanya saja hal tersebut kadang tidak berlaku bagi petani karena kebutuhan yang menurut responden selalu mendesak misalnya untuk kebutuhan anak sekolah atau bahkan untuk makanan sehari-hari bagi petani yang menjadikan bertanam kakao ini sebagai penghasilan utama mereka sehingga mereka mencari alternatif sendiri dengan menjual hasil kakao kepada tengkulak yang datang langsung kepada petani dan menjual dengan harga yang diminta oleh pedagang pengumpul tersebut tanpa melihat harga pasarannya lagi.

Menurut informasi yang didapat dilapangan bahwa pemerintah Kabupaten Sigi akan membuat pasar induk untuk penjualan hasil kakao petani, namun sampai saat ini menurut petani hal tersebut belum terealisasi. Koperasi yang adapun tidak berjalan sebagaimana mestinya. Maka pemerintah perlu segera mengambil tindakan agar petani kakao tidak lagi mengalami kesulitan dalam melakukan pemasaran atas hasil kakao petani. Dari segi kemitraan, membangun kemitraan dengan pelaku usaha sangat penting bagi kelangsungan pemberdayaan terhadap petani. penyuluh swadaya sendiri yang juga merupakan seorang pelaku utama angkat tangan untuk hal ini karena mereka sendiri juga masih banyak yang menjual hasil pertaniannya ke pedagang pengumpul. Belum ada kemitraan yang terjalin untuk melakukan penjualan ataupun kerjasama usaha untuk pengolahan hasil tanaman kakao itu sendiri, selain itu hal yang sulit juga untuk melakukan penjualan ke kota atau ibukota provinsi adalah sarana yakni kendaraan untuk mengangkut coklat yang telah kering dan siap untuk dijual karena jarak yang sangat jauh sehingga petani akan 
merasa rugi jika harus menjualnya ke kota dengan perhitungan tenaga mereka dan uang bahan bakar yang harus mereka keluarkan dari hasil penjualan sehingga akan mengurangi penghasilan bersih mereka jika dibandingkan kalau mereka menjualnya ke pedagang pengumpul yang datang langsung untuk membeli kakao mereka dengan harga yang sama.

Berdasarkan jawaban yang diberikan oleh petani melalui persepsi mereka tentang peranan penyuluh swadaya bahwa penyuluh swadaya pada aspek agribisnis kakao hanya berperan pada proses budi daya, yang di antaranya adalah pemberian informaasi tentang pemangkasan, pemupukan, pengendalian hama dan penyakit. Sedangkan pada proses panen dan pascapanen serta pemasaran tidak berperan. Seperti halnya hasil penelitian dari Indraningsih (2010) yang mengatakan kondisi aktual yang terjadi pada materi penyuluhan masih didominasi teknik-teknik budidaya suatu komoditas untuk peningkatan produksi saja. Padahal kondisi yang diharapkan adalah adanya pengembangan sumber daya manusia dan peningkatan modal sosial, serta unsur ilmu pengetahuan, teknologi, ekonomi, manajemen, hukum dan pelestarian lingkungan hidup (UU RI Nomor 16 Tahun 2006).

Pada aspek agribisnis kakao penyuluh swadaya hanya berperan pada bidang budidaya saja, namun diluar hal tersebut penyuluh swadaya juga telah melakukan beberapa peran lain yakni perananperanan yang telah ditetapkan oleh pemerintah sebagai standard kompetensi kerja nasional indonesia (SKKNI) melalui Surat Keputusan Menteri Tenaga Kerja dan Transmigrasi Republik Indonesia nomor 29 tahun 2010 tentang penetapan SKKNI sektor pertanian bidang penyuluhan pertanian. Hal ini menjadi sesuatu yang penting karena dengan peranan tersebut dapat mendukung peranan penyuluh swadaya dan membantu petani dalam memberdayakan pribadinya dan kemudian bermanfaat lagi bagi pribadi petani lainnya.

Kementerian pertanian merinci kompetensi kerja penyuluh pertanian menjadi tiga bagian yakni kompetensi umum, kompetensi inti dan kompetensi khusus. Namun pada penelitian ini hanya mengambil satu bagian saja untuk melihat peranan lain yang dilakukan oleh penyuluh swadaya yakni kompetensi umum. Kompetensi umum adalah kompetensi yang berlaku untuk semua level penyuluh. berdasarkan hasil lapang bahwa penyuluh swadaya pada kenyataannya lebih berperan terhadap kompetensi umum ini.

Peranan ini akan menjadi kelebihan dari penyuluh swadaya karena mereka adalah orang yang dekat dengan petani sekaligus tinggal diwilayah petani sehingga interaksi antara petani dan penyuluh swadaya terjadi setiap harinya. Adanya hubungan yang baik antara penyuluh swadaya dan petani dalam penelitian ini dapat dipersentase sebesar 90,62\% dan tentunya keadaan tersebut didukung dengan kepercayaan yang diberikan petani kepada penyuluh, hal tersebut dapat dilihat dari hasil rata-rata dengan persentase sebesar $88,55 \%$, artinya bahwa penyuluh swadaya berperan dengan berkontribusi menjadi perpanjangan tangan pemerintah. Hal ini dilakukan dengan selalu memberikan informasi yang mereka dapatkan ketika penyuluh mengikuti pertemuan maupun pelatihan dan didukung pula sikap membuka diri pada lingkungan sekitar sehingga terjalin komunikasi yang baik dan berproses secara terus menerus, dengan demikian petani lebih terbuka terhadap permasalahan yang mereka hadapi dan dengan keterbukaan itu penyuluh swadaya lebih leluasa dalam menentukan tindakan apa yang harus dilakukan untuk mengatasi permasalahan dan mencarikan alternatif solusinya. Penyuluh swadaya perlu diberikan pelatihan tentang teknologi inovasi sehingga pemikiran mereka akan berkembang, tidak hanya hal-hal yang sudah biasa mereka lakukan, namun ada hal baru yang bisa membuat mereka lebih berdaya.

Selama ini penyuluh swadaya belum banyak dilibatkan dalam perencanaan penyuluhan maupun dalam pembuatan programa penyuluhan, mereka bekerja sebagai penyuluh hanya karena keinginan mereka untuk berbagi. Namun tentunya pemerintah perlu membantu peranan ini sebagai upaya untuk meningkatkan pemberdayaan petani khususnya petani kakao. Jika kita melihat dari persentasi persepsi petani terhadap peranan penyuluh swadaya berdasarkan SKKNI maka penyuluh swadaya merupakan seseorang yang memiliki potensi untuk menjadi narasumber bagi petani dengan persentasi sebesar 55,20\%. Hal ini perlu menjadi perhatian bagi pemerintah dengan memberikan kesempatan kepada penyuluh swadaya untuk mengikuti berbagai pelatihan secara bergiliran dengan penyuluh swadaya yang lain, bila perlu pemerintah bisa membuatnya 
sendiri dengan mengundang penyuluh swadaya dari semua kecamatan dibagi dalam dua tahap pelatihan sehingga diharapkan penyuluh swadaya dapat membantu tugas penyuluh PNS sebagai partner kerja yang saling membantu satu sama lainnya untuk mencapai tujuan penyuluhan.

Selain itu penyuluh swadaya juga merupakan pemberi motivasi yang handal bagi petani hal ini dapat dilihat dari persentasi rata-rata yang diberikan petani sebesar $87,50 \%$. Dari hasil wawancara diketahui bahwa sebagian dari petani kakao sebelumnya adalah petani vanili yang kemudian mengalihfungsikan lahannya untuk tanaman kakao karena melihat program yang ditawarkan pemerintah pada saat itu, namun rasa tidak percaya diri yang timbul dari petani memunculkan ketakutan bagi petani jika mereka gagal menanam kakao. Pada saat seperti inilah kemudian penyuluh swadaya hadir sebagai ketua kelompok tani maupun ketua Gapoktan yang datang untuk menguatkan para petani dan kemudian membantu mereka untuk tetap berdaya sehingga akhirnya mereka hingga saat ini masih menanam tanaman kakao.

Penyuluh swadaya adalah pendamping penyuluh PNS yang bila keduanya dapat bekerjasama dengan baik dalam melakukan penyuluhan maka tujuan dari sasaran penyuluhan akan berhasil dengan baik, hal ini disebabkan karena penyuluh swadaya yang juga merupakan ketua kelompok memiliki pengaruh terhadap petaninya dan memiliki tanggung jawab besar terhadap kemajuan petani yang dibinanya. Mardikanto (1993) mengungkapkan bahwa pemimpin kelompok mempunyai tanggung jawab sosial yang tinggi, dinamis dan selalu merasa terpanggil untuk menggerakkan masyarakat guna melakukan perubahan ke arah yang lebih baik. Maka dengan demikian apa yang diharapkan dari tujuan penyuluhan yang meliputi pengembangan sumber daya manusia dan peningkatan modal sosial akan tercapai dengan baik dan tentunya didukung pula oleh kebijakan dari pemerintah daerah untuk mencapai tujuan tersebut.

\section{Kesimpulan}

Berdasarkan hasil analisis dan pembahasan pada penelitian ini maka dapat diambil kesimpulan bahwa berdasarkan persepsi petani terhadap peranan penyuluh swadaya bahwa penyuluh swadaya telah berperan dalam mendukung intensifikasi kakao khususnya dibidang budidaya kakao, yang meliputi Pemberian Informasi pada proses pemangkasan, Pemupukan, pengendalian hama dan pengendalian penyakit. Peranan lain yang juga dilakukan oleh penyuluh swadaya adalah peranan yang telah ditetapkan oleh pemerintah dalam Standard Kompetensi Kerja Nasional Indonesia (SKKNI) diantaranya adalah Sebagai Pemberi motivasi dan dukungan kepada petani, perlakuan yang sama dari penyuluh swadaya, adanya kepeercayaan yang diberikan petani kepada penyuluh swadaya sebagai seseorang yang mampu membantu petani dalam pemecahan masalah yang dihadapi. Pendekatan bottom up lebih mudah diterima namun tetap dalam pengawasan sosial (social controx) yang efektif. Pengetahuan petani masih dikatakan kurang tentang peranan penyuluh swadaya karena sebagian petani tidak mengetahui tugas dan fungsi yang sebenarnya dari penyuluh swadaya sehingga mereka hanya menganggap bahwa peyuluh swadaya hanya sebagai ketua kelompok saja. Mereka belum mengetahui peranan yang saharusnya dilakukan oleh penyuluh swadaya yang diatur dalam juklak pemberdayaan penyuluh swadaya.

\section{Daftar Pustaka}

American Marketing Association. 2003. Perilaku Konsumen dan Implikasi dalam Strategi Pemasaran. Terjemahan Nugroho Setiadi J. Jakarta (ID): Prenada Media.

Ancok D. 1997. Teknik Penyusunan Skala Pengukuran. Yogyakarta (ID): Pusat Penelitian Kependudukan Universitas Gajah Mada.

[BPS Sulawesi Tengah] Badan Pusat Statistik Provinsi Sulawesi Tengah 2012. Sigi dalam Angka. Sulawesi Tengah: Badan Pusat Statistik Provinsi Sulawesi Tengah.

[Depdiknas] Departemen Pendidikan Nasional. 2003. Undang-Undang Nomor 20 Tahun 2003 tentang Sistem Pendidikan Nasional. Jakarta (ID): Depdiknas.

David B. 1995. Pokok-Pokok Pikiran dalam Sosiologi. Jakarta (ID): Raja Grafindo Persada. Indraningsih KS, Sugihen BG, Tjitropranoto P, Asngari PS, Wijayanto H. 2010. Kinerja Penyuluh dari Perspektif Petani dan Eksistensi Penyuluh Swadaya sebagai Pendamping 
Penyuluh Pertanian PNS. [Catatan Penelitian]. Analisis Kebijakan Pertanian 8: 313-315

Kotler P, Keller KL. 2009. Manajemen Pemasaran. Jilid 1 [Terjemahan] Bob sabran. Edisi 13. Jakarta (ID): Erlangga.

Maalouf WD. 1993. Planning for Effective Training: A Guide to Curriculum Development. Rome (IT): The United Nations.

Mardikanto T. 1993. Penyuluhan Pembangunan Pertanian. Surakarta (ID): Sebelas Maret University Press.

Maswadi. 2011. Agribisnis Kakao dan Produk Olahannya Berkaitan dengan Kebijakan Tarif Pajak di Indonesia. Jurnal Tek.Perkebunan dan PSDL 1(2):24.

Menteri Tenaga Kerja dan Transmigrasi Republik Indonesia. Nomor: Kep.29/men/iii/2010. Tentang penetapan SKKNI Sektor Pertanian Bidang Penyuluhan Pertanian [Internet]. Jakarta (ID): Nakertrans.

Mosher AT. 1991. Menggerakkan dan Membangun Pertanian. Jakarta (ID): Yasaguna

Najib M, Rahwita H. 2010. Peranan Penyuluh Pertanian dalam Pengembangan Kelompok Tani di Desa Bukit Raya Kecamatan Tenggarong Seberang Kabupaten Kutai Kartanegara. Jurnal Zira'ah 28(2): 116-128. Kalimantan Barat (ID): Ziraa'ah.

Nazir M. 2009. Metode Penelitian. Jakarta (ID): Ghalia Indonesia.

Purnaningsih N. 1999. Pemanfaatan Sumber Informasi Tentang Usahatani Sayuran oleh Petani. [Tesis]. Bogor (ID): Sekolah Pascasarjana. Institut Pertanian Bogor

Padmowihardjo S. 1994. Psikologi Belajar Mengajar. Jakarta (ID): Universitas Terbuka.

Pusat Penyuluhan Pertanian Badan Penyuluhan dan Pengembangan SDM Pertanian Kementerian Pertanian. 2012. Petunjuk Pelaksanaan Pemberdayaan Penyuluh Pertanian Swadaya. Jakarta (ID): Kementan.
[Permentan] Peraturan Menteri Pertanian. 2008. Pedoman Pembinaan Penyuluh Pertanian Swadaya dan Penyuluh Pertanian Swasta. Jakarta (ID): Permentan.

[Republik Indonesia] Undang-Undang No 16 Tahun 2006 Tentang Sistem Penyuluhan Pertanian. Perikanan dan Kehutanan.

Singarimbun M, Effendi S. 1989. Metode Penelitian Survei. Jakarta (ID): LP3S.

Siregar THS. Riyadi S. Nuraeni L. 2007. Budidaya. Pengolahan dan Pemasaran Cokelat. Jakarta (ID): Penebar Swadaya.

Stanton WJ. 1993. Fundamental of Marketing. Jakarta (ID): Erlangga

Subejo. 2008. Sistem Penyuluhan di Jepang: Konsep. Peran dan Perkembangan Penyuluhan Pertanian dan Pedesaan. Yogyakarta (ID): UGM

Sudarta W. 2002. Pengetahuan dan Sikap Petani terhadap Pengetahuan Hama Terpadu. Jurnal Sosial Ekonomi Pertanian dan Agribisnis SOCA 2(1).

Sugihartono et al. 2007. Psikologi Pendidikan. Yogyakarta (ID): UNY Press.

Sumardjo. 1999. Transformasi Model Penyuluhan Pertanian menuju Pengembangan Kemandirian Petani. [Disertasi]. Bogor (ID): Sekolah Pascasarjana. Institut Pertanian Bogor.

Soekanto S. 2002. Sosiologi Suatu Pengantar. Jakarta (ID): Raja Grafindo Persada.

Toha M. 2003. Perilaku Organisasi Konsep Dasar dan Aplikasinya. Jakarta (ID): Raja Grafindo Persada.

Van den Ban AW. H.S. Hawkins. 1999. Penyuluhan Pertanian. Yogyakarta (ID): Penerbit Kanisius.

Yamin M. 2004. Strategi Pembelajaran Berbasis Kompetensi. Jakarta (ID). Gaung Persada Press. 